Egyptian Journal of Aquatic Biology \& Fisheries

Zoology Department, Faculty of Science,

Ain Shams University, Cairo, Egypt.

ISSN $1110-6131$

Vol. 22(5): 447 - 460 (2018)

www.ejabf.journals.ekb.eg

\title{
Use of humic acid and Yucca extract as a benefactor on water quality and their impact on some hematological and histological parameters of Oreochromis niloticus
}

\author{
Reham, A. A ${ }^{\mathbf{1}}$; Mounes, H. A. M. ${ }^{1}$ and Ahmed, K. M. ${ }^{2}$. \\ 1- Department of Limnology, Central laboratory for Aquaculture Research, \\ Abbassa, Agricultural Research Center, Egypt. \\ 2- Fish Production Branch, Department of Animal Production, Faculty of \\ Agriculture, Ain Shams University, Cairo, Egypt. \\ *Corresponding Author: r_abdelwahab2010@yahoo.com
}

\section{ARTICLE INFO \\ Article History: \\ Online: Jan. 2019 \\ Keywords: \\ Humic acid \\ Yucca schidigera \\ Immunity \\ Nile Tilapia \\ Ammonia}

Received: Nov. 1, 2018

Accepted:Dec.28, 2018

\begin{abstract}
Adding natural product such as Humic acid (Humabol) and Yucca schidigera extract to enhance water quality under scarce water exchange regiment; has numerus effects on both fish environment and health. Yucca showed significant reduction on $\mathrm{NH}_{3}$ and $\mathrm{NO}_{2}$ levels, while humic acid showed significant reduction on orthophosphate and total phosphorus compared to negative control; in addition to maintaining acceptable growth rate under designed experimental conditions. Furthermore, the hematological study showed that, Yucca and humic had positive effect on Red cell indices values such as, HCT, MCV, MCH, MCHC as well as WBCs total count and the proportion of the NEU, MONO, ESO and LYM of the treated treatments. Also, the histological study of gills, liver, stomach and intestine highlighted the tissue protective effect manifested by Yucca and humic.
\end{abstract}

\section{INTRODUCTION}

Yucca schidigera, a native plant of the southwestern USA and Mexico, has aroused interest in livestock and poultry farms operations due to its ability to absorb ammonium (Headon and Walsh 1993). Yucca schidigera has high levels of steroidal saponins and polyphenolics (Cheeke et al. 2006). The extract of Yucca has a potential to modulate nitrogen metabolism and reduce ammonia excretion (Sarkar 1999; Kelly \& Kohler 2003).

$Y$. schidigera extract could be used in aquaculture in the same way as it has been done in terrestrial animal, in the literature $Y$. schidigera extract has been used as an additive in fish feeds in order to improve nitrogen / protein metabolism and thus reduce ammonium excretion (Francis, (2001), Kelly \& Kohler 2003, El Saidy and Gaber 2004b and Gaber, 2006).

There have been numerous studies on the use of $Y$. schidigera in feeds for various fish species, such as, Nile tilapia O. niloticus (Gaber 2006) and hybrid tilapia O. niloticus x O.mossambicus (Kelly \& Kohler 2003) and channel catfish (Kelly \& Kohler 2003).

Johnston et al. (1982) suggested that surface components of $Y$. schidigera extract could aid in nutrient absorption. Y. schidigera extract has been used 
successfully to control the accumulation of ammonium in animal housing, as well as to reduce the concentration of ammonium in water, faecal odor in animal excrement (Cheeke 2000, Hristov et al. 1999, Killeen et al. 1998, and Wallace et al. 1994) and improve both survival and performance of cultured animals (Sarkar 1999a, Sarkar, (1999b).

(Kelly and Kohler 2003, Santacruz-Reyes and Chien 2010) revealed that $Y$. shidigera can reduce ammonia buildup produced by biogenic sources, hydrogen sulfide and other compounds affecting fish health in both fresh and seawater.

Humic substances are the most ubiquitous carbon substance on the surface of the earth, found in almost every drop of water and in almost all soils. Humic substances are the most widely distributed organic products of biosynthesis on the face of the earth (Tan, 2003).

Humic acid is one of the major components of humic substances which are dark brown and major constituents of soil organic matter. Humic acid contributes to soil chemical and physical quality and acts as precursor of some fossil fuels. They can be found in peat, coal, many upland streams and ocean water. It arises by the microbial degradation of bio-molecules (lipids, proteins, carbohydrates and lignin) dispersed in the environment after the death of living cells (Marinsky et al., 1995).

Gressler et al., 2016; Shin et al., 2016 and Sinha et al., 2014, 2013 and Ching et al., 2009, highlighted that; aquatic organisms exposure to excessive unionized ammonium $\left(\mathrm{NH}_{3}\right)$; led to increase of blood and tissue ammonia concentration, which subsequently manifest numerous health problems to fish such as; high mortality, growth and reproductive performance reduction, hyperactivity, tissue erosion and degeneration, immunosuppression, as well as, neurotoxicity, oxidative stress, oxygen supplement impairment, convulsions and coma.

Hence, the present study aims to evaluate the effect of Humic acid (Humabol) and Yucca schidigera extract on improving the quality of fish environment in light of the limited water exchange, preserve the life of the fish and keep them alive with the possibility of obtaining acceptable growth if possible, the effect of ammonia stress on blood parameters such as, hematocrit, erythrocyte count, leukocyte count. In addition to, histological investigation to gills, liver and kidney for detecting stress related alterations.

\section{MATERIALS AND METHODS}

This work was conducted in Fish Production Branch, Faculty of Agriculture, Ain Shams University, Cairo, Egypt, to investigate the effect of Humic acid (Humabol) and Yucca schidigera extract on water quality, blood parameters and histology of Tilapia (Oreochromis niloticus).

An experimental design of three treatments and two replicas was carried out. A total of 180 Oreochromis niloticus (L.) of about $(51 \mathrm{~g} \pm 0.02)$ initial average weight were randomly allotted in the six concrete ponds $\left(2 \mathrm{~m}^{3} /\right.$ each $)$, with thirty fish / pond. All the three treatments were tested using a commercial diet $(3 \mathrm{~mm} 30 \%$ protein floating pellets; from Alleraqua Egypt). ( $\left.\mathrm{T}_{1}\right)$ was a negative control treatment, $\left(\mathrm{T}_{2}\right)$ commercial natural liquid extract of $Y$. schidigera of concentration of $1 \mathrm{mg} / \mathrm{m}^{3}$ (Egyvit) and $\left(\mathrm{T}_{3}\right)(0.2 \%$ Humic acid / kg feed (Salem and Shehab El- Din (2010) were administrated in water for 93days. During the experimental period, fish were fed the commercial diet at (08:00 and 14:00 h) six days a week at a rate of $2.5 \%$ of tilapia biomass and one day starvation till the end of the experimental period.

The experimental ponds were supplied with fresh dechlorinated water every 15 days and no aeration were applied throughout the experimental period. 
At the experiment wrap-up, five fish from each treatment were homogenized and frozen.

\section{Water quality}

Water temperature and dissolved oxygen (oxygen meter WPA 20 Scientific Instrument) were measured daily at 7 a. m, according to APHA (1992). Water samples were taken every 2 weeks to determine $\mathrm{pH}$ using glass electrode $\mathrm{pH}$-meter (Digital Mini-pH Meter, model 55, Fisher Scientific, USA), total ammonia concentration was measured by HACH comparison apparatus using HACK kits (Hach Co., Loveland, Colorado, USA). The percentages of unionized ammonia $\left(\mathrm{NH}_{3}\right)$ calculated from multiplying the total ammonia value by the appropriate factor according to the following equation $\mathrm{NH}_{3}-\mathrm{N}=\mathrm{A} / 100 \mathrm{x}$ total ammonia (Boyd 1995), Nitrate was measured by phenoldisulphonic acid method, using spectrophotometer (model Milton Roy 21D), at wavelength of $410 \mathrm{~nm}$, nitrite-nitrogen was measured by diazodyzing method; using spectrophotometer (model Milton Roy 21D) at wave length of $543 \mathrm{~nm}$, total alkalinity $\left(\mathrm{mg} / 1\right.$ as $\left.\mathrm{CaCO}_{3}\right)$ was measured by titration against sulfuric acid, after adding methyl orange (M.O) as an indicator, total hardness (mg / 1 as $\mathrm{CaCO}_{3}$ ) was measured by titration against Ethylene diamine tetra acetic acid (EDTA) after adding ammonium buffer solution, and erochrom black $\mathrm{T}$, as an indicator, total nitrogen, total phosphorus after the samples have been digested using persulfate digestion method, the concentration of total phosphorus was measured using the spectrophotometer (model, WPA Linton Cambridge UK) at wave length of $880 \mathrm{~nm}$ and orthophosphate using spectrophotometer (model Milton Roy 21D) at wave length of $880 \mathrm{~nm}$ according to (APHA,1985).

\section{Blood sampling}

At the end of the experiment; twelve $O$. niloticus from each treatment were randomly taken and anaesthetized. Blood was collected from each individual trough caudal venous puncture with the use of $1 \mathrm{ml}$ syringe washed with $\mathrm{K}_{2}$ EDTA; the sampling tubes contained $\mathrm{K}_{2}$ EDTA as anticoagulant (Faggio et al., 2014).

\section{Automatic haematological and biochemical analysis}

Hematological parameters were performed using automated blood testing machine auto-haematology analyzer Rayto model RT7200 to determine some haematological parameters Such as: haemoglobin $(\mathrm{Hb})$, Packed cell volume (HCT or PCV), Red blood cell (RBC), White blood cell (WBC), Mean corpuscular volume (MCV), Mean corpuscular haemoglobin $(\mathrm{MCH})$, Mean corpuscular haemoglobin content (MCHC) were investigated.

\section{Histological Investigation}

Six fish were taken dissected from each treatment to obtain the gills, liver, stomach and intestine and fixed in Davidson's modified solution Fournie et al., 2000; later on, samples transverse sections were cut and stained with hematoxylin and eosin protocol. The examined tissue samples per treatment were 3 organs $\mathrm{x} 3$ replications $\mathrm{x}$ 5 examined fields in each slide for abnormalities detection by a light microscope and were photographed by a fluorescence microscope Leica DM2500 Germany.

\section{Growth parameters}

\section{Average daily gain (ADG)}

Daily gain was estimated according to the following formula:

$$
\begin{aligned}
& A D G=\left(W t_{2}-w t_{1}\right) / t \\
& \text { Where: } \quad \text { wt }_{1}=\text { first fish weight in grams. } \\
& \mathrm{wt}_{2}=\text { following fish weight in grams. } \\
& \mathrm{t}=\text { period in day. }
\end{aligned}
$$




\section{Statistical analysis}

The data were analyzed by using the GLM procedure with One-way analysis of variance (SAS, 2009), Differences among means were tested for significance according to Duncan's multiple rang test (Duncan, 1955). The following model was used to analyze the obtained data:

$\mathrm{Yij}=\mathrm{u}+\mathrm{Ti}+\mathrm{eij}$

Where:

Yij =observation.

$\mathrm{U}=$ the overall mean.

$\mathrm{Ti}=$ the effect of treatment.

eij= random error.

\section{RESULTS AND DISCUSSION}

\section{Water quality parameters}

The average water temperature obtained in the current experiment $(27.35$ $30.85^{\circ} \mathrm{C}$ ) is suitable for all physical, chemical and biological processes in pond water as described by Boyd (1979). (Balarin, 1988), the performance of tilapia was very good when the temperature ranged between 25 and $30^{\circ} \mathrm{C}$. The optimum temperature for natural growth, reproduction and tilapia growth is about 25 and $32^{\circ} \mathrm{C}$, (Chervinski, 1982). In the present study, DO readings were between (0.765 to 1.35 $\mathrm{mg} / \mathrm{L}$ ) from week 2 till the end of the experimental period which considered very low concentrations of oxygen for tilapia fish according to Riche and Garling (2003), the preferred DO for optimum growth of tilapia is higher than $5 \mathrm{mg} / \mathrm{L}$. (Tsadik and Kutty, 1987). On the lower limit, Ross (2002) observed that $3 \mathrm{mg} / \mathrm{L}$ DO concentration should be the minimum for optimum growth of tilapia, The $\mathrm{pH}$ values in the current study ranged from 6.83 to 7.54 , which were in the safe and preferred range for the conservation of live fish and the growth of tilapia according to Ellis (1973), who showed that water with $\mathrm{pH}$ values of about 6.5 to 9 at dawn it is most suitable for fish production and acidic and alkaline death points for fish approximately 4 and $11 \mathrm{pH}$ respectively. Yucca extract in treatment 2 significantly reduced $\mathrm{NH}_{3}$ compared with the control and humic treatment Fig. (4).

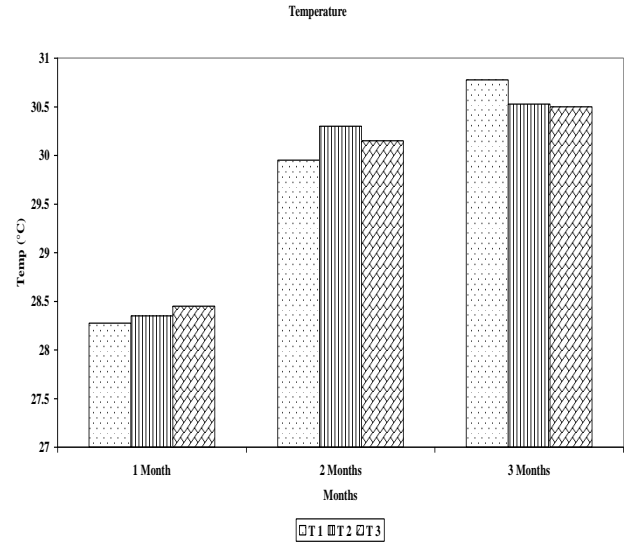

Fig. 1: Changes in water temperature ${ }^{\circ} \mathrm{C}$ in the different treatments

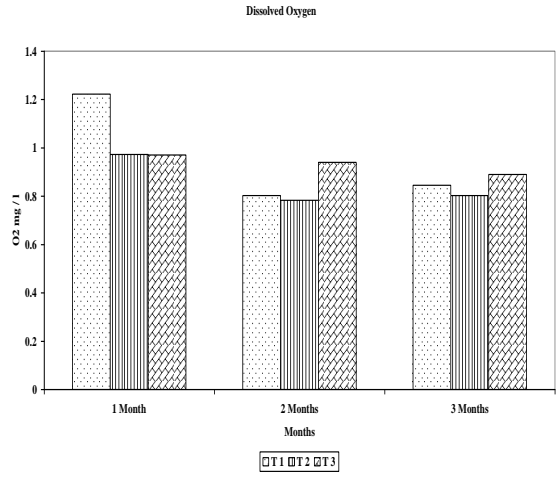

Fig. 2: Effect of different treatments on water D.O levels (mg / l). 


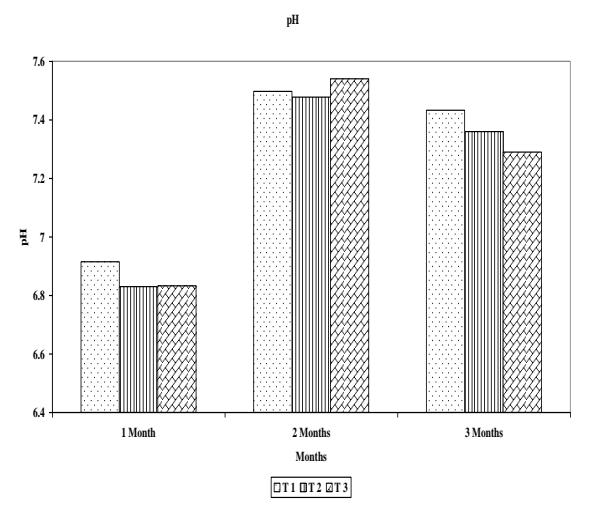

Fig. 3: pH Values of the treatments during the experiment.

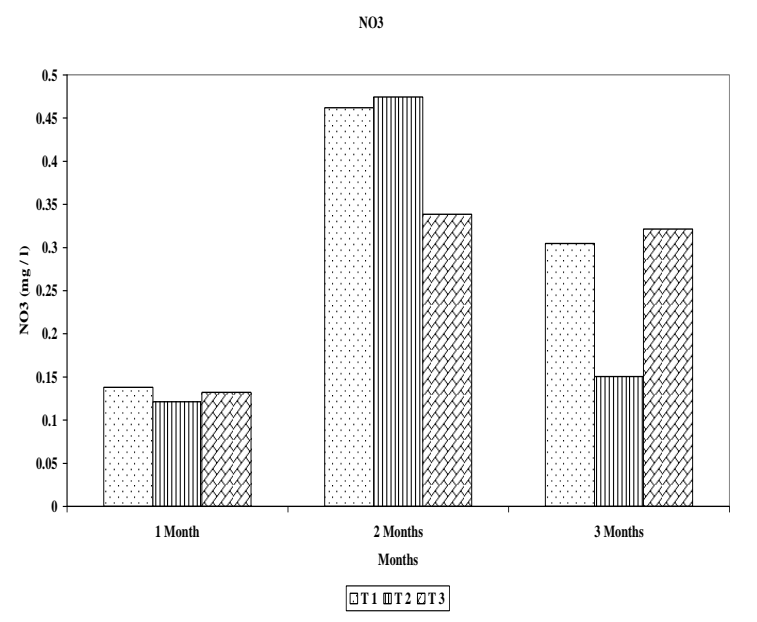

Fig. 5: Changes in water $\left(\mathrm{NO}_{3}-\mathrm{N}\right)$ values $(\mathrm{mg} / \mathrm{l})$ during the experimental period

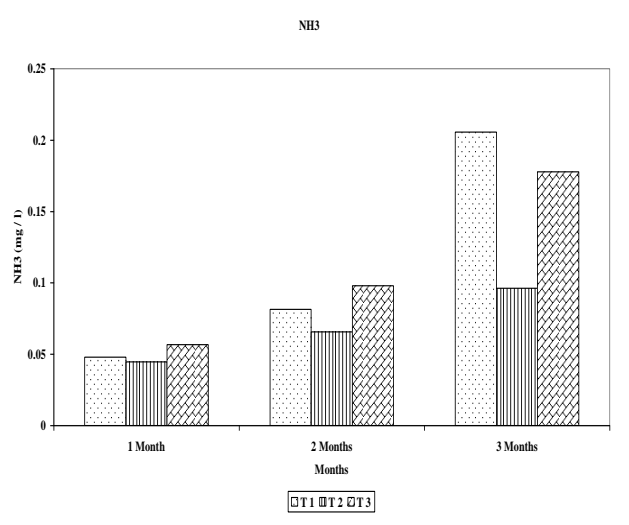

Fig. 4: The concentrations of water $\mathrm{NH}_{3}-\mathrm{N}$

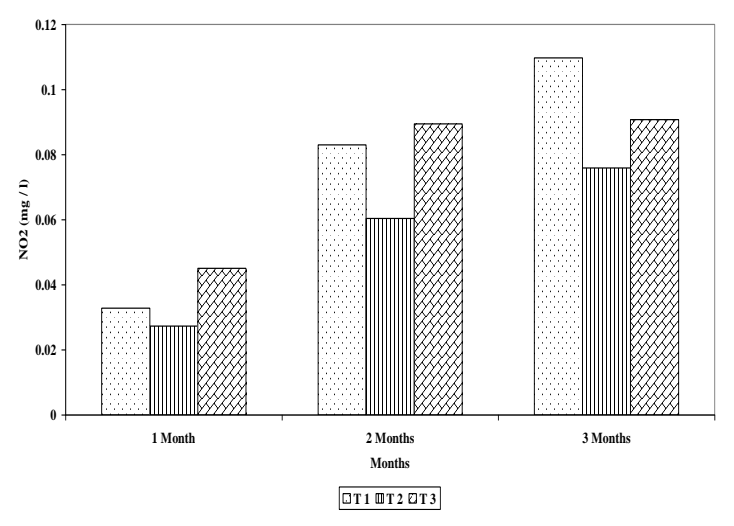

Fig. 6: Changes in $\left(\mathrm{NO}_{2}-\mathrm{N}\right)$ values $(\mathrm{mg} / \mathrm{l})$ during the experiment

Jacques and Bastien (1989) stated that the use of $Y$. schidigera extract contribute in decreasing ammonia accumulation by increasing bacterial use of ammonia and acting as a urease inhibitor. The results in these study are agree with those of Headon and Dawson (1990) and El-Saidy, and Gaber, (2004) who reported that reduction of ammonia could be due to either binding of ammonia with some fraction of $Y$. shidigera or by conversion of ammonia to another compound. The water of treatment 2 showed increase nitrate levels as ammonia levels declined, subsequently, nitrite concentrations decreased. Data of Figs (7 and 8) revealed that the highest value of orthophosphate and total phosphorus were acquired by the control treatment followed by yucca and humic treatments, humic acid has the capability of reducing the negative effect of high dosage of phosphorus (P) in treatments. Humic acid acts as supplier and storehouse $\mathrm{P}$ for algae and phytoplankton in aquatic ecosystem (Bakhsh, 2001).

Ayuso et al. (1996) reported that the addition of humic acid to fish water positively affects the availability of $\mathrm{P}$ and micronutrients by increasing uptake rates of these nutrients by algae. From Figs (9 and 10) it was noticed that humic treatment gave insignificant increase in total hardness and total alkalinity than the other two treatments $(\mathrm{P}<0.05)$. These results are in agreement with results who obtained by (Mounes, 2015), who noted that treatment without humic acid gave the lower values in total hardness (102.08 vs $150.15 \mathrm{mg} / \mathrm{L}$ ) and total alkalinity (137.03 vs $144.43 \mathrm{mg} /$ L) compared with treatment with humic acid. 


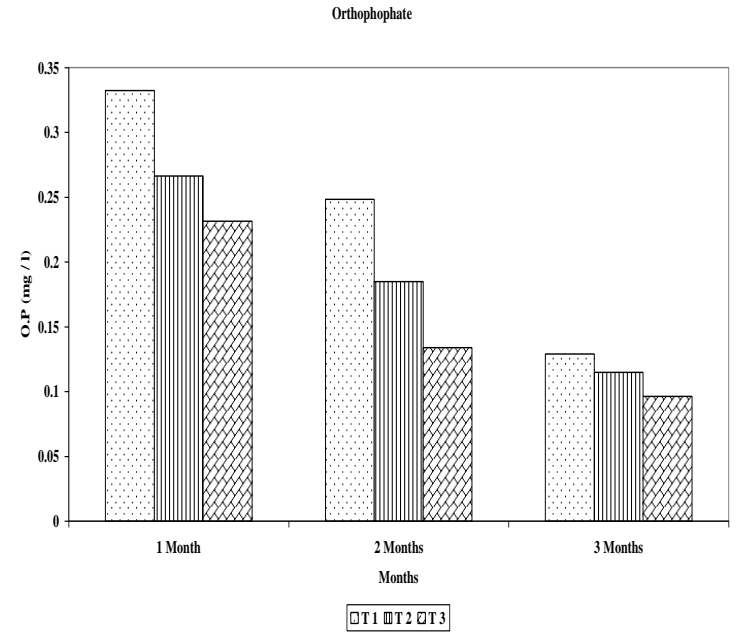

Fig. 7: Change in water orthophosphate concentrations (mg / 1)

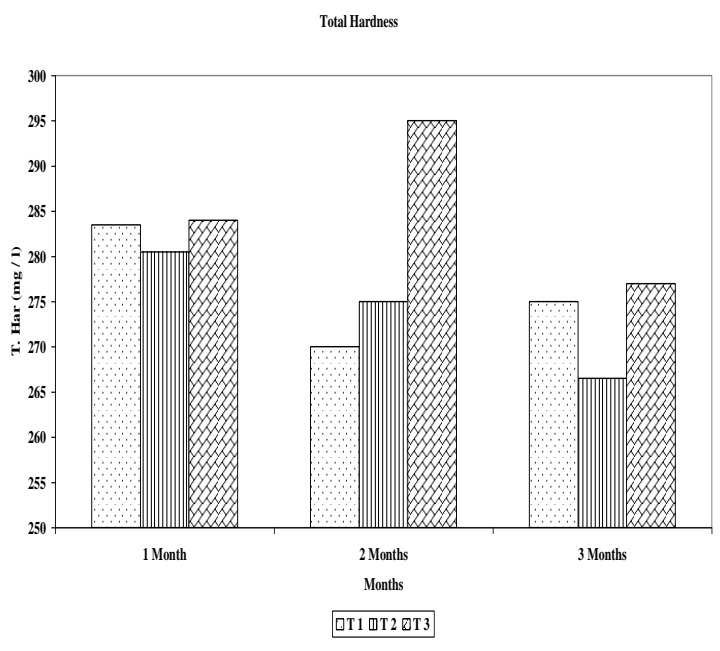

Fig. 9: Changes in water Total Hardness values (mg /1) during the experiment

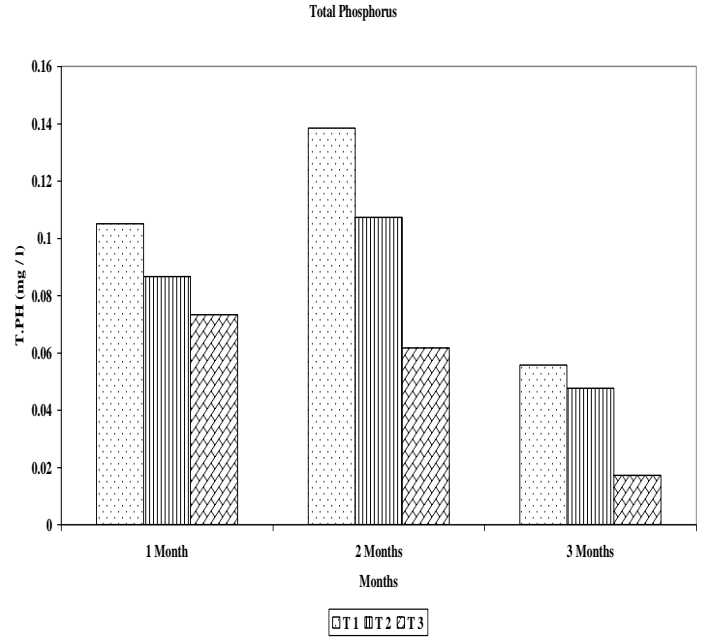

Fig. 8: Mean concentrations of water total phosphorus (mg / l)

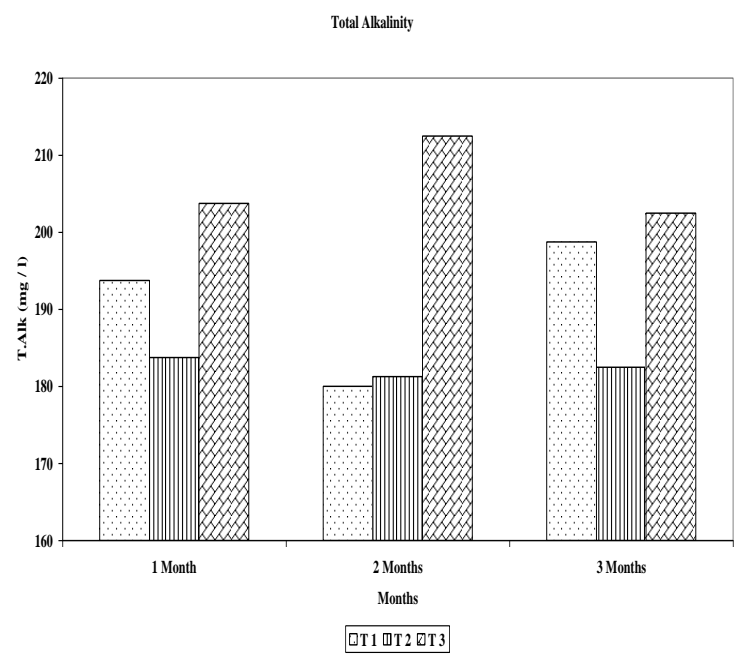

Fig. 10: Total Alkalinity of the treatments during the experiment

\section{Growth Parameters}

Growth responses in this experiment was acceptable in all treatments, considering that the main objective of this experiment was to preserve the life of the fish and keep them alive with the possibility of obtaining acceptable growth if possible. The means of fish body weight for the experimental treatments are presented in Table (1). The data clearly indicated that $\mathrm{T}_{1}$ have the highest final body weight and average daily gain $(89.91 \pm 0.2$ and $0.41 \pm 0.1 \mathrm{~g} / \mathrm{fish})$ while the lowest one $(75.79 \pm 0.2$ and $0.26 \pm$ $0.1 \mathrm{~g} / \mathrm{fish}$ ) was recorded for $\mathrm{T}_{3}$. These results are in disagreement with results who obtained by (Kelly \& Kohler 2003), who stated that channel catfish fed diets containing the yucca extract improved growth compared with the control diet.

Table 1: Growth performance parameters of $O$. niloticus in different treatments

\begin{tabular}{|l|c|c|c|}
\hline & Treatment 1 & Treatment 2 & Treatment 3 \\
\hline Initial Body Weight (g / fish) & 50.86 & 51.55 & 51.2 \\
\hline Final Body Weight $(\mathbf{g}$ / fish) & $89.81^{\mathrm{a}} \pm 0.2$ & $83.04^{\mathrm{ab}} \pm 0.2$ & $75.79^{\mathrm{b}} \pm 0.2$ \\
\hline Average Daily Gain (g/ fish) & $0.41^{\mathrm{a}} \pm 0.1$ & $0.33^{\mathrm{b}} \pm 0.1$ & $0.26^{\mathrm{c}} \pm 0.1$ \\
\hline
\end{tabular}




\section{Haematological and biochemical analysis}

The obtained haematological data showed that yucca treatment obtained the highest RBCs count followed by humic treatment and control Fig. (11). The treated treatments humic and yucca hemoglobin value compared to control Fig. (12); both RBCs and HB values were statistically not significant, while the parameters related to Red cell indices values such as, HCT, (MCV) define the size and hemoglobin content (MCH, MCHC) of red blood cells were in favor of treated treatments as shown in Figs. (11 to 13). The WBCs total count of the treated treatments had elevated in humic and yucca treatments respectively as shown in Fig. (15). whereas, the proportion of the NEU, MONO, ESO and LYM showed significant difference among treatments except for the latter as illustrated in Figs. (15 \& 16).

$\mathrm{RBCs}$

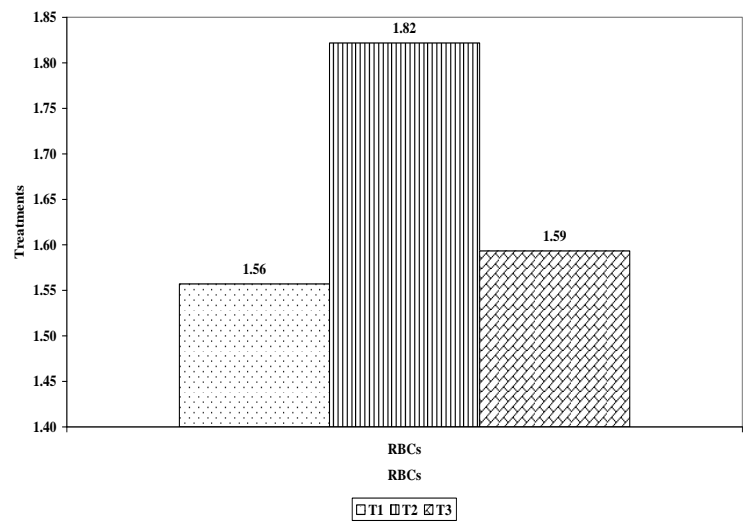

Fig. 11: Illustrates red blood corpuscles RBCs count among different treatments MCH \& MCHC

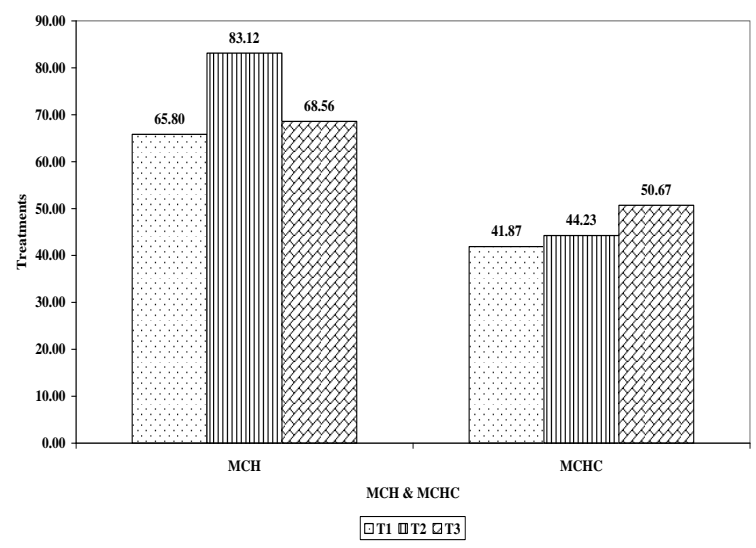

Fig. 13: $\mathrm{MCH} \& \mathrm{MCHC}$ values measured by pictogram (pg) among treated treatments WBCs \& LYM

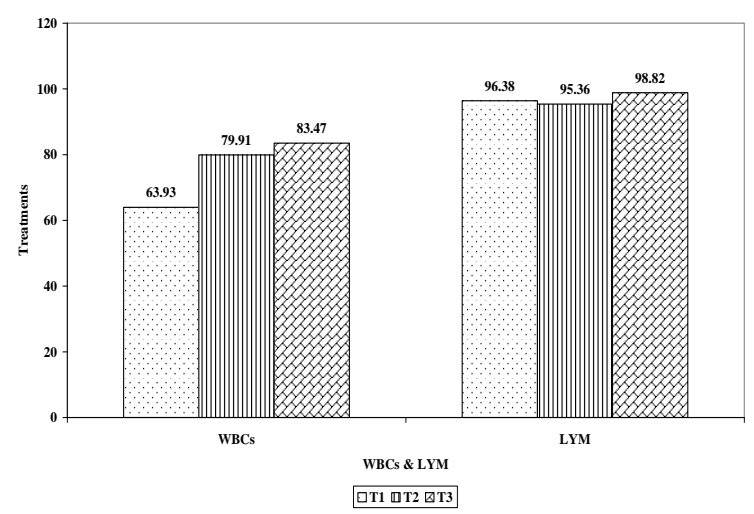

Fig. 15: Illustrates WBCs \& LYM for all treatments

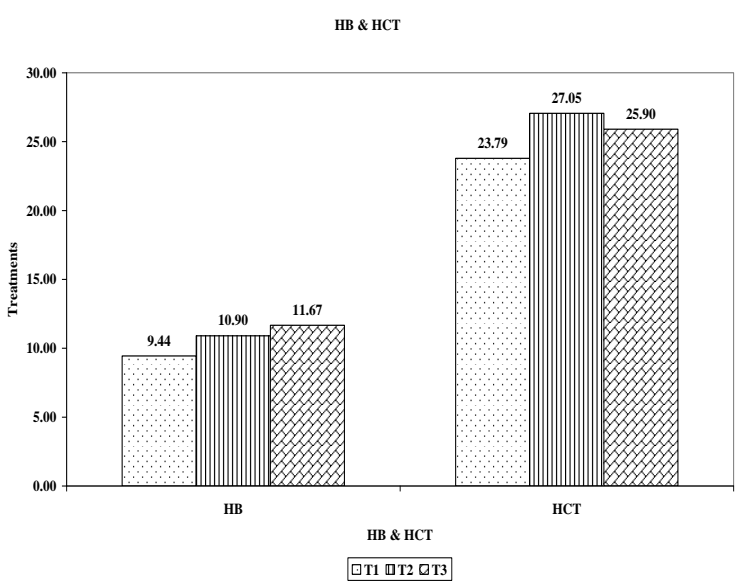

Fig. 12: Showing hemoglobin $(\mathrm{Hbg} / \mathrm{dl})$ and HCT values among treated treatments

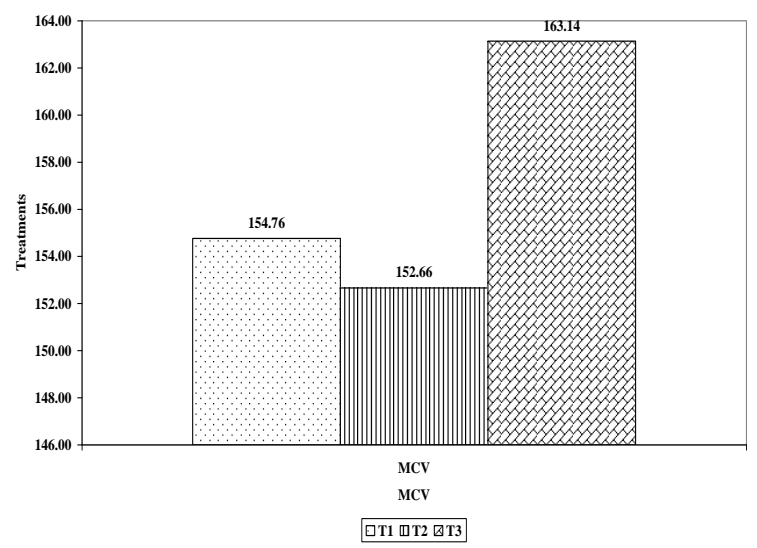

Fig. 14: MCV values measured by among treated treatments

NEU \& MONO \& EOS

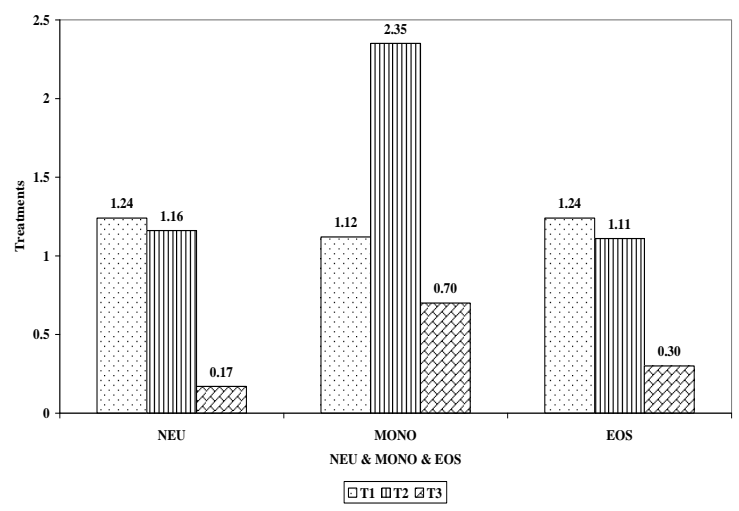

Fig. 16: Showed NEU \& MONO and EOS 
Ammonia prolonged exposure especially $\mathrm{NH}_{3}$ could cause multifactorial pathogenesis to multiple organs such as gills, liver, kidney, spleen and thyroid in fish, crustaceans and mollusks El-Sherif and El-Feky, 2008.

This result was in agreement with Shin et al., 2016 and Kim et al., 2017; who stated that, high ammonia levels affect both Rockfish Sebastes schlegelii, sablefish Anoplopoma fimbria by induced the following effects; hemato-somatic index and hematological parameters, such as RBCs count, WBCs count, Hb and Ht Furthermore, $\mathrm{MCV}, \mathrm{MCH}$.

In addition to, the findings of EL-Sherif and El-Feky, 2008 and Abbas 2006, who stated that there was significant change in Nile tilapia and common carp Hct and $\mathrm{HB}$ values with the increase of $\mathrm{NH}_{3}$ concentration in water.

\section{Histological Investigation}

There were signs of disfiguration, hemorrhage and shorter main filaments and secondary lamellae in the vast majority of the control individuals gill tissues compared to treated treatments. Additionally, they manifested other signs such as, reduction in mucus secretion, hyperplasia, telangiectases, degeneration of secondary lamellae and outflow of liquids as illustrated in Fig. (17).

Meanwhile, both treated treatments showed intact gill tissue with longer main and secondary filaments as well as heavier mucus coating for the gills epithelial tissue which was more pronounced in yucca treatment. hence Sinha et al., 2014 and Benli et al., 2008; stated that mucous may play an important role in excessive mucus production, gill epithelium thickening. Da Costa et al., 2015 also stated that, humic influence gill epithelium function by altering membrane permeability, enhance ion uptake.

The histological examination of intestinal tissue of the control treatment showed large intestinal lumen with shorter intestinal villi compared to the treated treatments which showed small intestinal lumen and taller villi especially in yucca treatment and there were no pronounced symptoms Fig. (18). Moreover, macrophages were present in the control intestinal sections which indicated immune response to inflammation, slight degeneration, vacuolization and fibrosis were present.
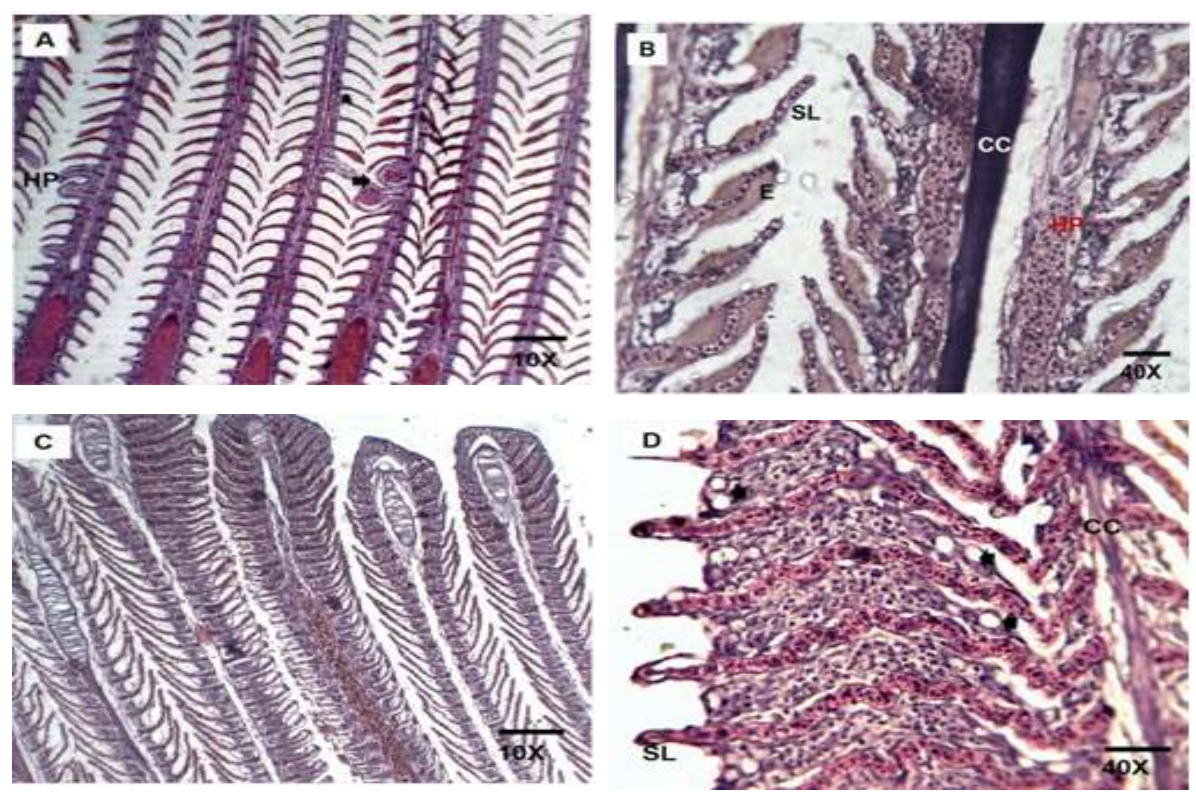

Fig. 17: Cross section in tilapia Gills showing the difference in size between control $(\mathrm{a}, \mathrm{b})$ and treated treatments (c, d). The magnified field in (B) showing chondrocytes (CC), Effusion (E), Hyperplasia (HP), secondary lamella (SL), telangiectases black arrow; while (D) shows the thick mucus cover on secondary lamella and mucus cell proliferation (MC) 


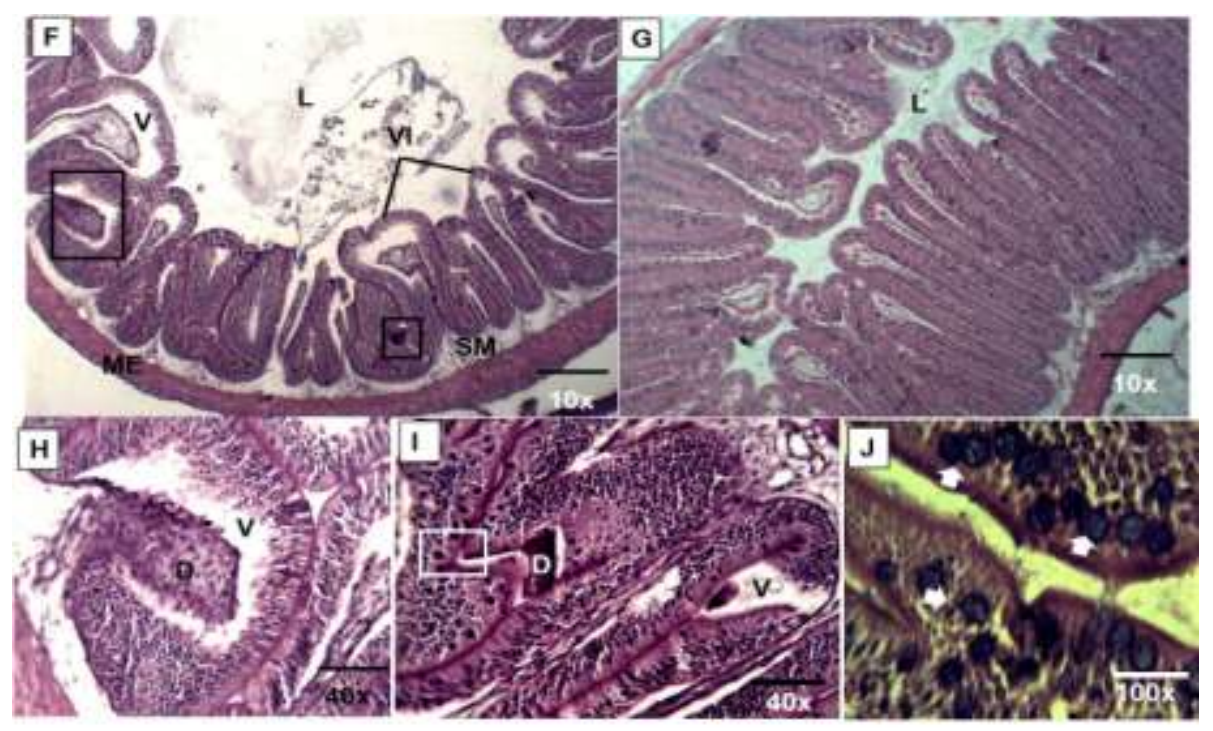

Fig. 18: Cross section in tilapia intestinal canal showing the difference in (L) lumen and (Vi) villi size between control (a) and (b) treated treatments which shows no changes in intestine folds. The magnified fields in C, D and E showing (d) degeneration and (v) vacuolization of intestinal villi and the arrows refers to microphages presences control specimens.

During samples taking the control treatment showed friable liver tissue. Histological examination of hepatic tissue section showed degenerated and vacuolated hepatic cells in control, while the treated treatments showed intact hepatic membrane structure and centric nuclei, however, there were rare occurrences of degeneration and vacuolization in humic treatment compared to the control in the same field of vision Fig. (19).

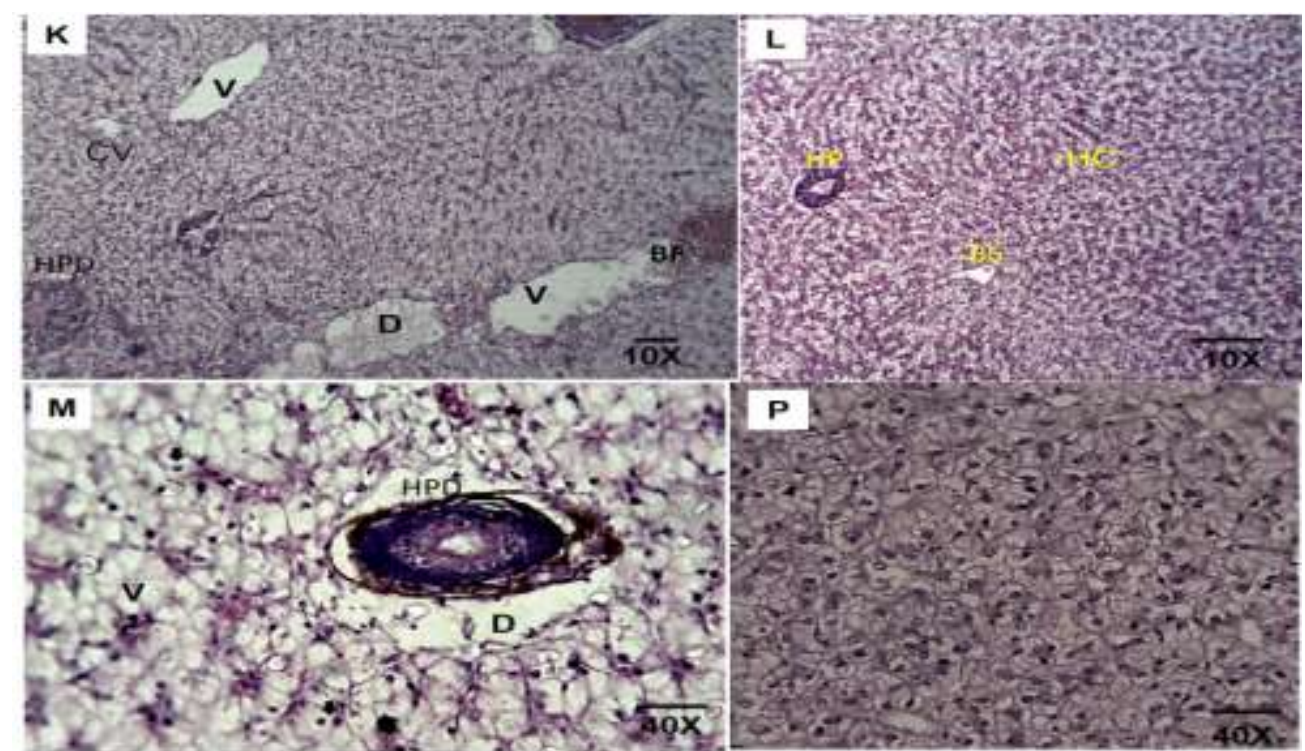

Fig. 19: Cross section in tilapia liver showing the difference in hepatic structure between control (f) and treated treatment $s(G)$. The magnified fields in $H$ highlighting the degeneration in Hepatopancreas (HP) and arrows shows the displacement of nucleus. section (I) shows hepatic cells with normal structures. Central vein (CV), Hepatic cells (HC), Hepatopancreas (HP), degenerative Hepatopancreas (HPD), Blood sinus (BS), blood infiltration (BF).

Kidney tissue in the control showed signs of degeneration of kidney glomerulus, dissociation tissue and liquid outflow while treated treatments with humic or yucca extract showed no significant abnormalities (Fig. 20). 


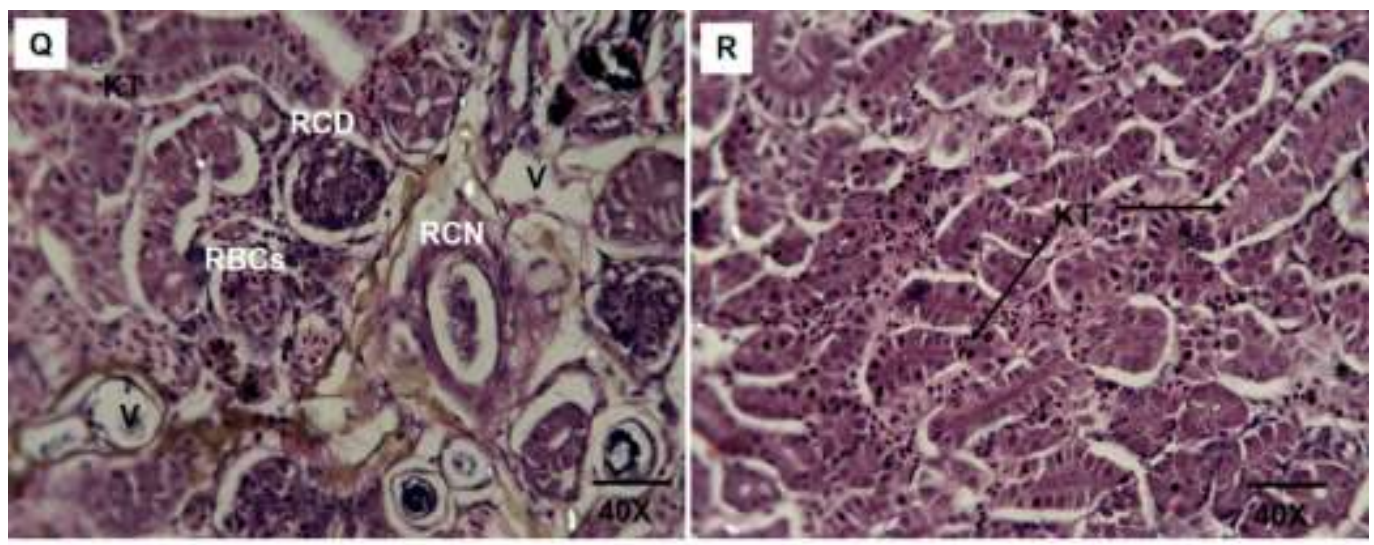

Fig. 20: Cross section in tilapia kidney showing striking differences between $\mathrm{J}$ control and $\mathrm{K}$ treated treatments; The control showing signs of Renal corpuscle degeneration (RCD), Renal corpuscle necrosis $(\mathrm{RCN})$ dissociation of kidney structures, while, treated treatments show slight dissociation of kidney structures with good shape kidney tubules (KT).

Intestine of control treatment showed the presence of macrophages, which indicated immune response to inflammation, which came in agreement with the findings of Rodrigues et al. (2010); who recorded the same action as response to inflammation in the intestinal mucosa. Our histological findings in control liver and kidney were supported by the findings of Benli et al. (2008); who stated that, ammonia causes liver glycogen to vacuolate due to energy malfunction and degenerative vacuolization and focal necrosis were present. While, Abbas (2006) found that, there was significant increase of liver and kidney tissue necrosis or dysfunction in common carp that agrees with or findings in control treatment histological sections.

\section{CONCLUSION}

It was noted from the results obtained that the yucca extract had the greatest effect on the elimination of harmful nitrogen compounds, which had the best effect on improving water quality and thus the environment surrounding fish, while the humic acid had the greatest effect on the availability of phosphorus compounds to benefit. Both yucca and humic acid reduced the effect of ammonia stress, so it is recommended to use both of them to improve water quality in the coming water poverty in the near future.

\section{REFERENCES}

Abbas, H. H. (2006). Acute toxicity of ammonia to common carp fingerling (Cyprinus Carpio) at different pH levels. Pak.J. Biol.Sci., 9 (12): 2215-2221.ISSN 10288880.

American Public Health Association (APHA), (1985). Standard methods for the examination of water and waste water (16th edition). Washington, D. C.

American Public Health Association (APHA), (1992). American Public Health Association standard Methods for the Examination of Water and Waste water, 22 nd ed. Washinton.

Ayuso, M.; Hernandez, T.; Garcia, C. and Pascual, J. (1996). Stimulation of barley growth and nutrient absorption by humic substances originating from various organic materials. Biores. Technol. 57: 251 - 257. 
Bakhsh, H. K. (2001). Influence of humic acid on water quality and growth of algae in freshwater ecosystem. Msc: Thesis Faculty of Agriculture, Putra University, Malaysia.

Balarin, J. D. (1988). Development planning for tilapia farming in Africa, pp, 531538. Second international Symposium on tilapia in Aquaculture, ICLARM Conference proceedings 15: 633 p. Deveolpment of fisheries, Bangkok, management, Manila, Philippines.

Benli, A. Ç. K.; Köksal, G. and Özkul, A. (2008). Sublethal ammonia exposure of Nile tilapia (Oreochromis niloticus L.): Effects on gill, liver and kidney histology. Chemosphere 72: 1355-1358.

Boyd, C. E. (1979). Water quality in warm water fish ponds. Auburn Univ. Agric. Experiment Station, Auburn, Alabama, pp. 359.

Boyd, C.E. (1995). Bottom soils, sediment, and pond aquaculture, New York.

Cheeke, R. P. (2000). Actual and potential applications of Yucca schidigera and Quillaja saponaria in human and animal nutrition. J Anim Sci 77: 1-10.

Cheeke, P. R.; Piacente, S. and Oleszek, W. (2006). Anti-inflammatory and antiarthritic effects of Yucca schidigera:a review. Journal of Inflammation (London, England) 3: 6 .

Chervinski, J. (1982). Environmental physiology of tilapias. In:The Biology and Culture of Tilapias, ICLARM Conference Proceedings No.7 (ed. by R.V.S. Pullin \& R.H. Lowe-McConnell), pp. 119 - 128. ICLARM, Manila, Philippines.

Ching, B.; Chew, S. F.; Wong, W. P. and Ip, Y. K., (2009). Environmental ammonia exposure induces oxidative stress in gills and brain of Boleophthalmus boddarti (mudskipper). Aquat. Toxicol. 95: 203-212.

Da Costa, S. T.; Gressler, L. T.; Sutili, F. J.; Loebens, L.; Lazzari, R. and Baldisserotto, B. (2015). Effect of humic acid on survival, ionoregulation and hematology of the silver catfish, Rhamdia quelen (Siluriformes: Heptapteridae), exposed to different pHs. Zool. Curitiba 32: 215-224.

Duncan, D. B. (1955). Multiple range and multiple F-tests. Biomet. 11: 1-15.

Ellis, M. M. (1973). Detection and measurement of stream pollution. U. S. Bureau offish. Bull. 22: 267- 437.

El-Saidy, D. M. S. and Gaber, M. M. A. (2004b). Effect of yucca (Yucca schidigera) on water quality and growth performances of Nile tilapia (O. niloticus L) fingerlings. Egyptian Journal of Aquatic Biology and Fisheries 8: 33-50.

El-Sherif, M. S. and El-Feky, A. M. (2008). Effect of ammonia on Nile tilapia $(O$. niloticus) performance and some hematological and histological measures. 8th international symposium on tilapia in aquaculture.

Faggio, C.; Arfuso, F.; Piccione, G.; Zumbo, A. and Fazio, F. (2014). Effect of Three Different Anticoagulants and Storage Time on Haematological Parameters of Mugil cephalus (Linneaus, 1758). Turkish Journal of Fisheries and Aquatic Sciences 14: 615-621.

Fournie, J. W.; Krol, R. M. and Hawkins, W. E. (2000). Fixation of fish tissues. In: The laboratory fish, (Ostrander, G.K., ed.), pp. 569-578, Academic Press, San Diego.

Francis, G. (2001). Effects of butanol extract from Yucca schidigera powder on growth and metabolism in common carp (Cyprinus carpio L.). Effects of low levels of saponins on two common fish culture -common carp (Cyprinus carpio L.) and Nile tilapia (Oreochromis niloticus L.). 2001. Ph.D. thesis. University of Hohenheim, Germany, 160 pp. 
Gaber, M. M. (2006). The effects of plant-protein-based diets supplemented with yucca on growth, digestibility, and chemical composition of Nile tilapia $(O$. niloticus, L) fingerlings. Journal of the World Aquaculture Society 37: 74-81.

Gressler, L. T.; Sutili, F. J.; Loebens, L.; Saccol, E. M. H.; Pês, T. S.; Parodi, T. V.; da Costa, S. T.; Pavanato, M. A. and Baldisserotto, B. (2016). Histological and antioxidant responses in Rhamdia quelen sedated with propofol. Aquac. Res. 47: 2297-2306.

Headon, D. R. and Dawson, K. A. (1990). Yucca extract controls atmospheric ammonia levels. Feed Stuffs 62(29): 2-4.

Headon, D. R. and Walsh, G. (1993). "Yucca schidigera extracts and ammonia control". E. Collins, C. Boon, Eds. Int. Livestock Environment Symp. IV. ASAE. 1993. St. Joseph, MI. pp. 686-693.

Hristov, A. N.; McAllister, T. A.; van Herk, F. H.; Cheng, K. J.; Newbold, C. J. and Cheeke, P. R. (1999). Effect of Yucca schidigera on ruminal fermentation and nutrient digestion in heifers. Journal of Animal Science 77: 2554-2563.

Jacques, K. A. and Bastien, R. W. (1989). Waste management and odor control comprehensive planning needs for intensive agriculture. Pages 13-33 in T. P. Lyons, editor. Biotechnology in the feed industry. Proceedings of Alltech's 5th Annual Symposium. Alltech Technical Publications, Nicholasville, Kentucky, USA.

Johnston, N. L.; Quarles, C. I. and Fagerberg, D. J. (1982). Broiler performance with DSS40 Yucca saponin in combination with monensin. Poultry Science 61: $1052-1054$.

Kelly, A. M. and Kohler, C. C. (2003). Effects of Yucca shidigera extract on growth, nitrogen retention, ammonia excretion, and toxicity in channel catfish Ictalurus punctatus and hybrid tilapia O. mossambicus x O. niloticus. Journal of the World Aquaculture Society 34: 156-161.

Kim, J. H.; Park, H. J.; Hwang, I. K.; Han, J. M.; Kim, D. H.; Oh, C. W.; Lee, J. S. and Kang, J. C. (2017). Alterations of growth performance, hematological parameters, and plasma constituents in the sablefish, Anoplopoma fimbria depending on ammonia concentrations. Fish. Aquat. Sci. 20.

Killeen, G. F.; Connolly, C. R.; Walsh, G. A.; Duffy, C. F.; Headon, D. R. and Power, R. F. (1998). "The effects of dietary supplementation with Yucca schidigera extract or fractions on nitrogen metabolism and gastrointestinal fermentation processes in the rat". Journal of the Science of Food and Agriculture 76: 91-99.

Marinsky, J. A.; Reddy, M. M.; Ephraim, J. and Mathuthu, A. S. (1995). Computational scheme for the prediction of metal ion binding by a soil fulvic acid. Analytic Chimica Acta, 302: 309 - 322.

Mounes, H. A. M. (2015). Effect of using humic acid as a prebiotic with different protein levels in fish diets on water quality and productive performance of Tilapia and common Carp under Egyptian conditions. pHD: Thesis Faculty of Agriculture, Ain shams University.

Riche, M. and Garling, D. (2003). Fish: Feed and Nutrition. Feeding Tilapia in Intensive Recirculating Systems. 2003.

Rodrigues, A. P. O.; Pauletti, P.; Kindlein, L.; Delgado, E. F.; Cyrino, J. E. P. and Machado-Neto, R. (2010). Intestinal histomorphology in Pseudoplatystoma fasciatum fed bovine colostrum as source of protein and bioactive peptides. Sci. Agric. 67: 524-530.

Ross, L. L. (2002). Environmental physiology and energetic. Fish and Fisheries Series. 2002; 25:89-128. Accessed at Santacruz-Reyes R. A, Chien, Y. H. 
(2010). Yucca schidigera extract - A bioresource for the reduction of ammonia from mariculture. Bioresour Technol 101: 5652-5657.

Sarkar S. K. (1999). Role of plant glycocomponents (De-odorase) on water parameters in fish ponds. Journal of Environmental Biology 20: 131-134.

Sarkar S. K. (1999b). "Role of plant glycocomponents (De-Odorase) on freshwater prawn, Macrobrachium malcolmsonii in ponds". Journal of Environmental Biology 20: 299-301.

SAS, (2009). Statistical Analysis System, SAS User's Guide: Statistics. SAS Institute Inc. Editors, Cary, NC, USA.

Shin, Ki Won; Shin-Hu Kim; Jun-Hwan Kim; Seong Don Hwang and Ju-Chan Kang. (2016). Toxic Effects of Ammonia Exposure on Growth Performance, Hematological Parameters, and Plasma Components in Rockfish, Sebastes Schlegelii, during Thermal Stress. Fisheries and Aquatic Sciences 19, no. 1.

Sinha, A. K.; Matey, V.; Giblen, T.; Blust, R. and De Boeck, G. (2014). Gill remodeling in three freshwater teleosts in response to high environmental ammonia. Aquat. Toxicol. 155: 166-180.

Sinha, A. K.; Giblen, T.; Abd-Elgawad, H.; De Rop, M.; Asard, H.; Blust, R. and De Boeck, G. (2013). Regulation of amino acid metabolism as a defensive strategy in the brain of three freshwater teleosts in response to high environmental ammonia exposure. Aquat. Toxicol. 130-131: 86-96.

Tan, K. H. (2003). Humic matter in soil and the environment. Marcel Dekker, New York.

Tsadik, G. G. and Kutty, M. N. (1987). Influence of ambient temperature and dissolved oxygen on feeding and growth of the tilapia (O. niloticus) 1987.

Wallace, R. J.; Arthaud, L. and Newbold, C. J. (1994). Influence of Yucca schidigera extract on ruminal ammonia concentrations and ruminal microorganisms. Applied and Environmental Microbiology Vol. 60: 1762-1767.

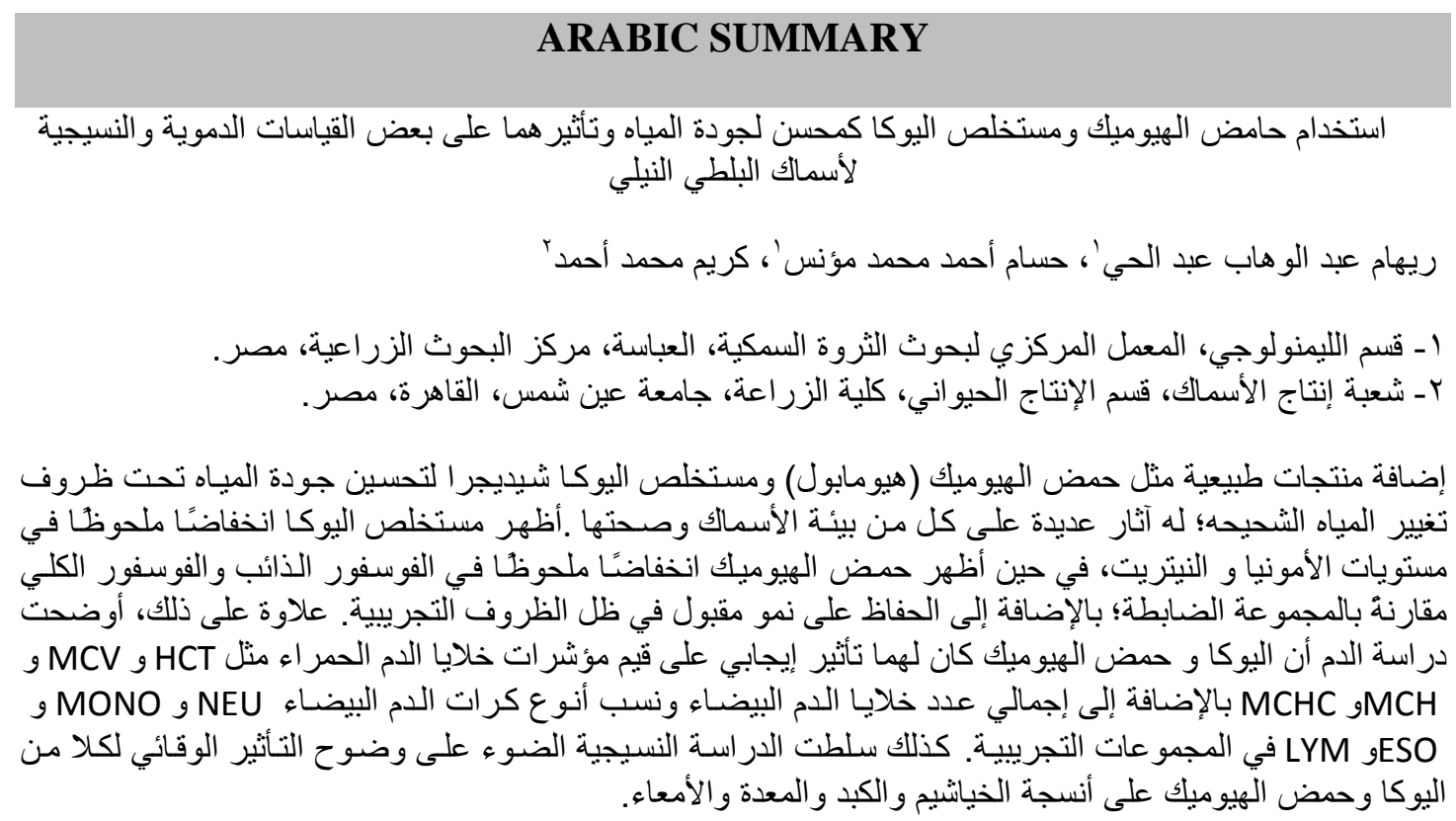

